\title{
Exploring tourism destination path plasticity
}

\author{
The case of coastal tourism in North Jutland, Denmark
}

\begin{abstract}
Path dependency is an acknowledged characteristic of tourism due to a majority of small and micro-sized firms and with that limited resourceful actors who can engage actively in path creation through development of new services and experiences. The aim of this paper is to analyse the socio-economic institutions that have facilitated the rise of coastal tourism, and on the basis of this to gauge the scope for incremental change, or plasticity, within the prevailing development path. The paper can be seen as an explorative study of the micro-dynamics of path plasticity, adopting a casestudy-based approach, exploring two coastal-rural destinations in North Jutland, Denmark. First a review of the literature on destination development and innovation is undertaken in order to identify key issues concerning continuity and change in tourism as a spatially embedded socio-economic activity. Then a conceptual framework for the analysis is outlined, inspired by traditions within institutionalism. Thirdly, the empirical analysis begins by identifying the key institutions supporting the rise of North Jutland as a successful international tourist destination in the 1980s and 1990s, and finally we discuss the extent to which scope for path plasticity can be found within this framework in the current climate of crisis, focusing especially on the role of combinatorial knowledge and policy agency. It is concluded that coastal tourism despite resemblances of an institutional 'iron triangle' actually is a more flexible structure which allows for a considerable degree of incremental change, provided that the actors involved are willing to engage in innovative development activities within the existing institutional framework.
\end{abstract}

Keywords: Coastal tourism, destination development, path dependency, path plasticity, destination governance

\section{Introduction}

Tourism has traditionally been perceived as characterised by a combination of labour-intensive hands-on services, a preponderance of small or micro firms, and limited innovation (HALKIER 2010b; Hall/Williams 2008; Malerba 2004b; WEIERMAIR 2006). Such characteristics would seem to make tourism a sector in which path dependency would be particularly pronounced due to shortage of actors with sufficient resources to engage actively in path creation through development of new services and experiences. Indeed, even when tourist destinations are interpreted from a development-oriented "life-cycle" perspective (BUTLER 1980/2006), a contrast is assumed between long periods of stable path dependent evolution and shorter conjunctures of possible path creation where new development directions are defined by actors capable of modifying key features of the destination in order to renew its appeal to potential visitors.
In recent decades the competitive pressure on destinations across Europe has greatly increased due to the growth of internet-based services and deregulation of the European airspace by the European Union (EU) which has led to a rapid spread of a new budget-airline business model and the opening up of new long-haul mass destinations in the Far East (BIEGER/WitTMER 2006; Halkier 2010a; Hall/Page 2002). Especially coastal destinations in rural regions in northwestern Europe which are not served by Ryanair and others have suddenly had to cope with the fact that large parts of their traditional visitorbase were now tempted away by new and exciting tourist destinations that had become visible, accessible and affordable. North Jutland, Denmark's primary coastal holiday destination, is a good example of a previously successful destination having to face stagnating visitor numbers, and hence creation of a new development path could mean the difference between decline and future prosperity. Given the considerable invest- 
ments already undertaken in tourist infrastructure within the region, not least in terms of selfcatering holiday homes (LARSEN et al. 2012), the attraction of exploring the scope for variation within the existing institutional set-up is, however, considerable. This makes the notion of path plasticity (STRAMBACH 2010; StrambaCH/ HALKIER 2013) interesting as an alternative framing of change processes in the destination, focusing on incremental rather than sudden and comprehensive forms of change.

The aim of this paper is to analyse the socio-economic institutions that have facilitated the rise of coastal tourism, and on the basis of this to gauge the scope for path plasticity, focusing especially on the role of access to knowledge from outside the region and/or sector and policy agency. This focus reflects two assumptions that will be expanded on below: Firstly, that extra-regional and extra-sectoral sources of knowledge are particularly important for innovation in internationally oriented destinations; secondly, that the well-established complexity of tourist destinations makes public coordination and proactivity important in utilising opportunities offered by path plasticity. As the paper can be seen as an explorative study of the micro-dynamics of path plasticity, it adopts a case-study-based approach, exploring two coastal-rural destinations, Toppen af Danmark and Mariagerfjord in North Jutland, Denmark (Fig. 1).

Fig. 1: The two Danish coastal tourism destinations used as case studies

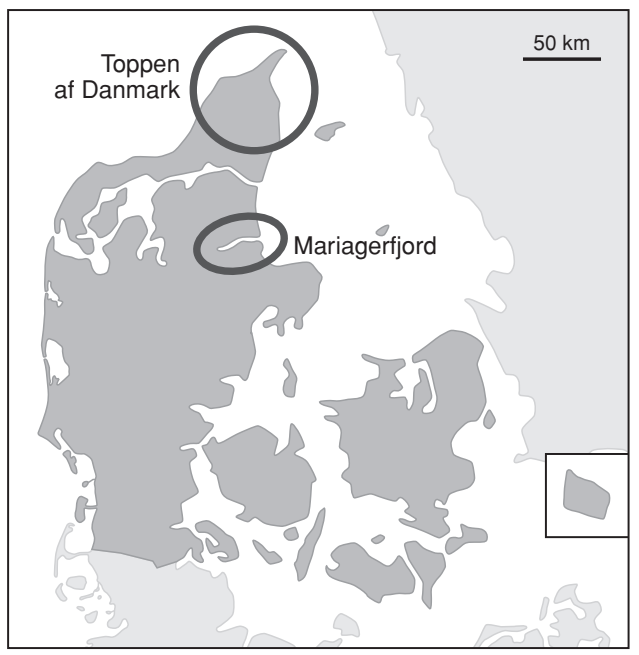

Cartography: Harald Krähe
The text proceeds in four main steps. First a review of the literature on destination development and innovation is undertaken in order to identify key issues concerning continuity and change in tourism as a spatially embedded socio-economic activity. Then a conceptual framework for the analysis is outlined, inspired by traditions within institutionalism. Thirdly, the empirical analysis begins by identifying the key institutions supporting the rise of North Jutland as a successful international tourist destination in the 1980s and 1990s. Finally we discuss the extent to which scope for path plasticity can be found within this framework in the current climate of crisis, focusing especially on the role of combinatorial knowledge and policy agency.

\section{Continuity and change in tourism}

In the literature on regional economic development the issue of path dependency and lock-in has received extensive attention (see e.g. HASSINK 2005; MARTIN/SUNLEY 2006; STRAMBACH/ HALKIER 2013), but in research on the development of tourist destinations an explicit adoption of such concepts and perspectives is still relative rare. The notion of path dependency has been employed in studies of the development of particularly aspects of destination development as a way to conceptualise the impact of the wider context. This is exemplified by a study of the socio-political context for the framing of the development of a world heritage site (CASSEL/PASHKEVICH 2008), or a study of partnership between public and private actors within destinations (BRAMWELL/COX 2009). But, perhaps unsurprisingly, the most important contributions have been made by researchers with a background in geography, such as Allan Williams (Hall/Williams 2008), and Alison Gill (Gill/ WiLliams 2011). A common feature of their work is the emphasis on the systemic features of tourism development that, all other things being equal, make destination development proceed along a path, often involving growth or, occasionally, stasis. Like in the literature focusing on the development of industrial districts, emphasis is given to the importance of property rights and patterns of ownership, political governance structures and regulation, and knowledge processes and workforce competences. This, taken together, result in strategic lock-in that makes it difficult to change the direction of development within a destination because prevailing institu- 
tions, organisational interests, dominant world views, and modes of operation all point towards the reassuring continuity entailed in more of the same. It is, however, important also to notice a common feature in the studies of path dependencies in tourism destination development, namely the importance attached to changing markets and demand patterns (WILLIAMS/BALAZ 2002), often positioned in the role as external and uncontrollable factors that fuel the need for change, either in terms of managing extensive growth or dealing with decreasing visitor numbers.

Despite the rather limited headway made by evolutionary geography concepts in the study of destination development, it is interesting to note that notions that are in many ways similar to those of path dependency and path creation can be found in the literature spawned by the seminal article by BUTLER (1980/2006) on the "tourism area life cycle". Here individual destinations are supposed to move through a series of growth stages - from exploration via involvement and development to consolidation - before eventually stagnating as they reach a level where critical resources have been depleted and the tourist destinations' carrying capacity exhausted. This interpretative scheme would seem to suggest a high degree of linearity in destination development where more and more actors, starting with local and eventually becoming multinational, exploit the same set of natural and cultural resources in order to target particular markets with certain forms of tourist experiences. The original scheme does, however, also involve important points of path creation, first when "local actors will $\ldots$ begin to provide facilities primarily or even exclusively for visitors" (BUTLER $1980 / 2006,6$ ), and later in the response of key actors to the challenge of stagnation which will determine whether the next stage will be destination redevelopment, decline or something in between. Despite the rather deterministic choice of the term 'cycle' for the approach, social actors clearly play crucial roles in expanding tourism activities both as producers and consumers of tourist experiences during the long stretch from exploration to stagnation (LAGIEWSKI 2006; WEAVER/LAWTON 2002), and thus a scope for development along different trajectories would still seem to exist. The work of e.g. Butler can therefore still be used as a means to assist in identifying the key social institutions from which path plasticity within tourist institutions may be derived.
Additional inspiration for such an endeavour can be found in a much smaller body of work that attempts to analyse tourism activities from an innovations system perspective. This perspective has been applied to nations (e.g. LUNDVALL 1992), sectors (e.g. Malbera 2004a), and regions (e.g. BraCZYK et al. 1998; COOKE et al. 2004), and despite the focus on innovation and development, the emphasis would still seem to have been on systemic features and hence the path dependent nature of development (HJALAGER et al. 2008, 23 ff.; OLSEN 2012). Although the notion of spatial patterns in the interplay between public and private actors in innovation processes would seem to lend itself well to a socio-economic activity where space in the form of destinations is important, few attempts have been made to interpret tourism development from an innovation systems perspective. The two most prominent examples are provided by Hall/Williams (2008, ch. 6) who discuss tourism as part of the wider regional innovation system, and the work of Hjalager and colleagues (cf. HJalager 2010; HJalager et al. 2008) where the innovation system concept is applied to both territorial units (destinations) and to e.g. events. In both cases the theoretical inspiration of the innovation systems approach would appear to be of a rather general nature, and consequently the main lesson that can be drawn from these writings would seem to be, much like in the case of Butler's tourist area life cycle, identification of actors and institutions which need to be taken into account in empirical analyses of processes of innovation and economic change in tourist destinations.

The general predominance of path dependency in the systemically-oriented macro-level literature would also seem to be reflected in microlevel studies of innovation within tourism, a small but rapidly growing literature (see e.g. Hall/Williams 2008; HJalager 2002, 2010; OECD 2006). Existing research generally points towards limited financial and human resources as factors that make small tourist firms relatively less innovative than firms in other sectors (HenRiKsen 2012; Novelli et al. 2006). Consequently, in a situation characterised by increasing competitive pressures, a prominent part of the answer to the challenge of furthering innovation in tourist destinations has been to promote development of networks between small firms in order to increase both coordination and knowledge sharing between actors so that it becomes easier for individual firms to contribute to the 
greater good that is renewal of the tourist experiences offered by the locality. While the need for coordination measures is widely agreed upon, their actual impact is less certain, with networks clearly making a positive difference in some cases, but as "the issues of innovation policy has not been given the priority they deserve in tourism research" (HJALAGER 2010, 9), many of the case studies of network initiatives for destination renewal remain of a rather descriptive nature.

It is, however, also interesting to notice that studies of tourism policy have identified a co-existence of different kinds of measures. Promotion of existing tourist experiences through marketing initiatives remains the most widespread and prominent form of public intervention (HALKIER 2010b; HALL 2008), and destination marketing is of course an excellent way of strengthening path-dependent development because it primarily involves alerting potential customers to the touristic experiences that are currently on offer. In contrast to this, in some tourism destinations public governance would also seem to have taken on a supplementary role in making firms and destinations more competitive (HALL/WILLIAMS 2008; HJALAGER 2010), but the recurring introduction of new innovation policies suggests a persistent perception of the need to try to create new development paths. On balance, while public policy may potentially play a crucial role in bringing about more or less radical forms of innovation in individual tourist destinations, the extent to which this strategy has been employed and, indeed, has been successful in bringing about renewal of the experience offer remains an empirical question where the outcome in individual tourist destinations depends on political priorities and the response of private actors to these.

All in all the existing literature on the development of tourist destinations would clearly seem to prioritise the identification of systemic features that may account for continuity and path dependency, presenting a continuous development occasionally intercepted by points of path creation in which a crisis is being confronted or new opportunities are being pursued. But embedded in this traditional path dependency/ creation dichotomy we have also identified elements of actor choice and intervention that suggest that the development of tourist destinations could also be meaningfully reinterpreted from a path plasticity perspective, and consequently the following section will try to outline a conceptual framework for such an undertaking.

\section{Towards a conceptual framework}

The conceptual framework for the subsequent empirical analysis is inspired by traditions within institutionalism, especially the work of Douglas North ( cf. HALKIER 2006, ch. 3; NORTH 1990) and Kathleen Thelen (MaHONEY/THELEN 2010; THELEN 2009). The key assumption is that institutions are as sets of rules on the basis of which individual or collective actors operate. Although institutions are by definition stabilising elements in social intercourse, the same rules may be interpreted and enforced in different ways, and in most societies at any point in time several institutions coexist. Taken together this ensures that a scope for change always exists, not just at critical junctures such as a crisis of a dominant institution, or profound changes in the external environment, but also in incremental ways where new ways of going about particular tasks gradually shifts the balance of activities in new directions, through strategic conversion of or externally induced drift, or introduction of new institutions to co-exist with or replace existing ones (MAHONEY/THelen 2010; STRAMBACH/ HALKIER 2013).

Translated into the context of tourist destination development, the starting point of the analysis will be to identify the key institutions that govern the relationship between the three groups of actors which are central to tourism as a social activity (BUTLER 1980 (2006); HALl 2008; WEAVER/LAWTON 2002), namely the visitors, the tourist industry, and government. Although all three groups generally consist of a multiplicity of actors with different resources and preferences (see e.g. IOANNIDEs/DebBaGe 1998; WeAVER/ LAWTON 2002) - e. g. leisure and business travellers, local attractions and multinational airlines, tourist offices and planning authorities - it is still possible to identify a number of key institutions on the basis of which their interactions take place (see Fig. 2).

Both in leisure and business tourism the relationship between visitors and service providers is conducted primarily on the basis of market relations. Visitors, either individually or collectively, generally have a range of options in terms of where to go, how to travel, where to stay, and/or what to do at the destination, and their choice of particular providers does not preclude different decisions being taken for future travel (HALKIER 2010b; WEAVER/LAWTON 2002).The interactions between tourist and providers of experiences/ 
Fig. 2: Actor groups and institutions in destination development

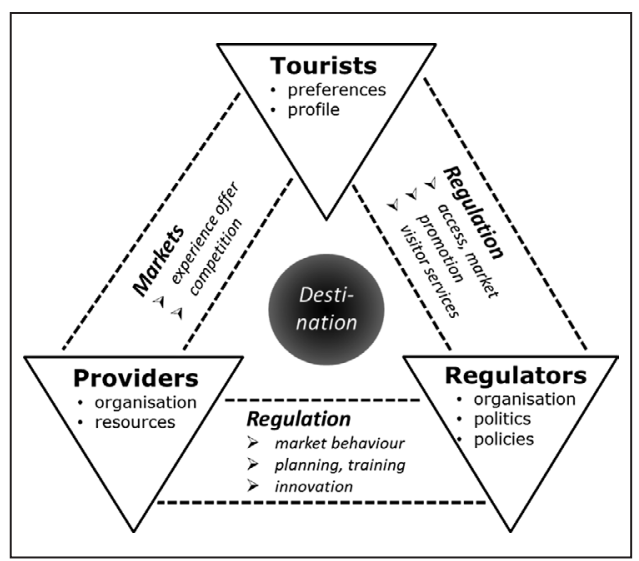

Source: own draft

services are in other words short-term market exchanges that do not involve hierarchical relations or long-term commitments (HALKIER 2006, ch. 3; THORELLI 1986), thereby making sure that individual providers and collective destinations perceive themselves as being subjected to competition from other providers/destinations offering similar experiences and services. Moreover, the interactions between the various providers at individual destination will also involve a combination of market and network relations: On the one hand they depend on the same visitors and hence cater for or compete in similar markets, while on the other hand this shared reliance on the same clients may also further more or less extensive forms of cooperation within the destination, both formally and informally (HALL/ Williams 2008; HJalager 2010; SHaw/WiLLIAMS 1998). In contrast to this, the relationship between regulators and both visitors and providers has a pronounced hierarchical element, because government has the ability to define specific rules about the behaviour of other actors, e.g. through instituting visa requirements for visitors or regulation of the right to build physical structures along the coast (HALKIER 2006; Hall 2008). At the same time the relationship between government and other actors also involve non-hierarchical relations, such as provision of advice, promotion and training, or establishing on-going collaborative arrangements in the form of e. g. networks or public-private partnerships in order to further innovation (DREDGE 2006; Hall 2008; HJalager 2010).
The relationships between the three key groups of actors may be institutionalised in a variety of ways, and from an institutionalist perspective the point is that these specific rules form the basis for the perceptions and agency of individual actors - and hence make it more or less difficult to bring about change within the destination, whether incremental or otherwise. Important preconditions for change and innovation in tourist destinations is knowledge that will allow the use of existing institutions to be modified, and capacity to guide actors in a concerted manner towards new ways of interacting. From a path plasticity perspective on change and innovation, three points are therefore important to note: Firstly, that destinations are of course not self-contained entities but extensively connected with actors and institutions outside the locality in which touristic activities take place - via incoming travellers, external ownership of local service providers, national policy regimes - and hence access to knowledge from outside the destination itself becomes important (CREVOISIER/ JENNERAT 2009; HALKIER 2010b), both in terms of what is known about visitors and competitors and how this knowledge is procured. Secondly, being able to combine knowledge across e.g. traditional sectoral boundaries (STRAMBACH/ Halkier 2013; Strambach/Klement 2012) is important in order to create experiences that set the destination apart from similar places elsewhere. In other words, the competitiveness of tourist destinations not only rest on what goes on internally among tourism actors within their immediate area of operation but also on how they engage, through knowledge exchange or otherwise, with actors external to the industry and/or the locality. Thirdly, especially in organisationally fragmented destinations characterised by a large number of small actors, policy agency by public bodies is likely to be necessary in order to coordinate activities and bring about a concerted momentum (DREDGE 2006; HALKIER 2010b; HALL 2008).

\section{Coastal tourism in North Jutland: actors and institutions}

The empirical analysis focuses on coastal leisure tourism in North Jutland, Denmark. In the following we will attempt to identify the key institutions, actors and processes that have dominated the development path of this socio-economic activity within the region. In the ensuing section the scope for path plasticity within the existing 
institutional framework will be explored, focusing both on the region as a whole and on two typical coastal destinations within it in particular.

The two case studies were undertaken as part of the EURODITE FP6 project sponsored by the $\mathrm{EU}$, researching knowledge dynamics in regions across Europe on the basis of knowledge biographies for territories and innovative economic activities (BUTZIN et al. 2007; BUTZIN/WIDMAIER 2012). For each of the two destinations the development of all-year tourism activities was illuminated through a series of qualitative interviews with policy-makers and other public and private stakeholders, supplemented by analysis of documentary resources (HALKIER et al. 2009; HeNRIKSEN/HALKIER 2009; THERKELSEN 2010).

Tourism is relatively important in North Jutland in the sense that tourism-related expenditure account for around $25 \%$ more of total expenditure than the national average, and along the northwestern coastline the share of tourism expenditure reaches between $75 \%$ and $200 \%$ above the national average (2010 figures, calculated on the basis of VisitDenmark 2012, 4). The total number of tourist overnight stays in rented holiday homes along the coast in North Jutland has remained relatively stable from 1992 to 2008 (see Fig. 3), but clearly in recent years the financial crisis has had an impact on visitation. Underlying these aggregate figures an important change has taken place, namely a gradual shift from mainly international towards domestic visitors, with neighbouring countries (especially Germany but also Norway and Sweden) contributing by far the largest share of international visitors (VisitDenmark 2012).

Families travelling with children constitute the most important type of travel group, and the major attractors are nature-based experiences with a strong social component like going to the beach, coupled with access to shopping and cultural attractions to cater for changing weather conditions (HJalager/JENSEN 2001; LARSEN 2012; VisitDenmark 2005). Unsurprisingly, this results in a high degree of seasonality in coastal tourism with most activity taking place from June through to August (HANSEN 2006; LARSEN/ THERKELSEN 2011). Visitors are primarily staying in self-catering accommodation, with international (and indeed German) visitors constituting no less than $72 \%$ of overnight stays in rented holiday homes in the period 2006-2011
Fig. 3: Overnight stays in rented holiday homes in North Jutland by origin

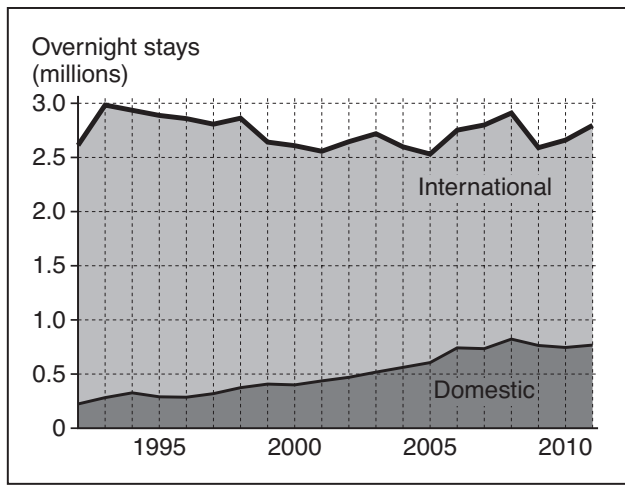

Source: Statistics Denmark 2012

Note: Due to the absence of regional breakdowns holiday home figures before 2007 are estimates calculated on the basis of the average North Jutland share of Danish holiday home bed nights in the period 2007-2011.

(calculated on the basis of Statistics Denmark 2012). The institutions that constitute the rules according to which the key components of the coastal leisure tourism product in North Jutland are being produced and consumed can in other words be summed up as follows.

With most visitors arriving by car from domestic locations or neighbouring countries (VisitDenmark 2010b), transport is organised by the travel groups themselves and essentially a spin-off from car ownership driven by everyday mobility needs (HALL et al. 2009, ch. 8) and hence something that is outside the immediate reach of policy-makers within North Jutland. The main form of accommodation for incoming tourists, the holiday homes, are owned by private individuals and predominantly rented through commercial letting agencies that organise marketing, booking systems, and associated services for visitors and owners (HJAlager 2009; THERKELSEN et al. 2012). In practice this means that foreigners and companies are barred from owning accommodation facilities classified as holiday homes, ownership is spread among a large number of individual (often non-local) Danish owners and owners tend to use facilities outside the main rental season in the summer, and only $18 \%$ of a total of nearly 200000 holiday homes in Denmark are let out on a commercial basis (HJALAGER 2009; THERKELSEN et al. 2012). The institutional setup in other words involves part-time commercial 
use of what are essentially private homes owned and used by Danish families for reasons that are not necessarily concerned with maximising their contribution to the regional visitor economy. The attractions that make leisure tourists travel to North Jutland - primarily natural amenities are predominantly public goods owned by public bodies, and their management is therefore determined by a wide range of concerns, including preservation of e.g. the coastal landscape for future generations (HALL et al. 2009; NYBERG 1995). On-site services - e.g. food, entertainment, arts, crafts - are provided primarily by small private firms, and hence subject to a high degree of seasonality e.g. in terms of opening or employment, because the availability of services will depends on the perception of the owners of the varying intensity of market demand (GETZ/ NiLSSON 2004; HANSEN 2006).

The role of government in relation to coastal tourism in North Jutland is multi-faceted and underlines the fact that tourism is just one among many concerns of public bodies operating within the region. The direct relationship of government to visitors combines direct access control on the basis of e.g. visa regulations - something that makes the region very accessible to neighbouring countries but less so for e.g. Russian visitors in search of seaside dacha-style leisure holidays - with a more visible role as promoter of Danish destinations in foreign markets through VisitDenmark and the regional destination management organization (DMO) VisitNordjylland, with local tourist offices providing on-site visitor information services (HALKIER 2011; KVISTGAARD 2006). Also in relation to private firms and other providers, the role of government is a dual one. On the one hand regulating ownership by barring foreigners to own properties designated as holiday homes and prohibiting construction of tourist and other facilities close to the coast. On the other hand attempting to bring about development and innovation among local firms and destinations by e.g. strengthening quality through targeted training programmes or creation of inter-firm networks (HALKIER 2011; HENRIKSEN 2012; KERNEL 2004). Although some regional bodies and inter-local destinations have increasingly come to view development of products, services and competences as important parts of their policy activities (HALKIER 2011; HENRIKSEN/HALKIER 2009), it is worth noting that marketing and visitor services still account for more than half of direct expenditure on tourism. All in all this would, perhaps unsurprising- ly, seem to suggest that the policies institutionalised by government, and indeed adhered to for several decades, would primarily tend to support existing leisure tourism activities in coastal destinations by encouraging more visitors to make use of existing experience offers. However, at the same time government regulation would also seem to conserve the existing industry structure by making it difficult for e.g. new providers of accommodation such as corporate holiday homes or seaside hotels to establish a presence. Consequently, the market for accommodation remains dominated by loosely coupled networks of individual actors for whom tourism is not a matter of survival in a competitive market place but rather a way of generating additional income through letting out the family holiday home.

The analysis of actors and institutions in North Jutland coastal tourism has in other words found a good fit between visitor profiles and experience offers - families travelling with children in search of primarily nature-based activities and relaxation - and a case of long-standing government intervention that supports existing actors and activities. A situation that could readily be described as a case of path-dependent development where more of the same is the likely prospect.

\section{Danish coastal tourism: from crisis towards all-year tourism?}

Despite the fact that coastal tourism in North Jutland has remained at the same level of visitation for nearly two decades, from the late 1990s onwards it has increasingly become enveloped in a discourse of crises that postulates the need for urgent remedial action. The timing would seem to suggest that the perception of crisis is linked to the declining number of international visitors, first in absolute numbers and later also relative to other Northern European countries in terms growth rates in key tourism indicators (VisitDenmark 2007b, 2010a). The gradual decrease in international visitor numbers would seem to reflect a combination of, on the one hand, changing demographic trends that eroded the traditional visitor base (fewer families with kids in the northern German federal states (Økonomi- og Erhvervsministeriet 2006), and, on the other hand, increased international competition fuelled by innovation in technology (internet booking) and business models (budget airlines) (HALKIER 2010b). Despite the systemic nature 
of increased market transparency and decreasing mobility cost, the responses to this challenge have not been of a radical, path-creating nature. In the following the initiatives of key actors aimed at addressing the stagnating demand for coastal leisure tourism experiences in North Jutland will be analysed in order to establish how they modify or support the prevailing institutions on basis of which this socio-economic activity operate.

\section{National responses}

Two major initiatives have emanated from the national level which, potentially, could have important bearings on the direction of development of coastal leisure tourism in Denmark. First, adjustments were made to planning regulations so that as of 2004 new areas were designated for additional holiday homes in peripheral areas close to, but not immediately adjacent to the coastline, including 14 localities in North Jutland (Skov- og Naturstyrelsen 2007). This limited relaxation of existing planning regulations did not free up space for holiday homes that was radically different from the existing stock of houses, if anything it was less attractive due to a greater distance to the beach. The initiative in other words primarily addressed the issue of limited capacity in the short summer season - only a minority of holiday homes are made available for commercial letting cf. above - but did so in a way that strengthened the institutions governing the accommodation of coastal leisure tourists, namely individual ownership of properties for mixed personal/commercial use. In practice this made the initiative depend on private actors whose inclination to invest in new accommodation capacity was of course influenced by the general uncertainties of global markets in the wake of the financial crises, and thus the effect of the, in terms of development path conservative, initiative is likely to have been limited.

The second major national-level initiative aimed to extend the coastal leisure tourism season significantly under the slogan "all-year tourism". Following an extensive scoping exercise (HANSEN 2006; Niras Konsulenterne 2006a, b), seven development destinations and 13 secondtier learning destinations were designated as the spatial focus. Here the aim was to develop new products and services that could make Denmark an attractive coastal leisure destination throughout the year, with adult couples and culinary ex- periences seen as being central to bringing international visitors to coastal destinations outside the (family holiday dominated) summer season (VisitDenmark 2007a, c). The all-year tourism initiative operated through transfer of financial resources to destinations who share knowledge and experience about building innovative activities and networks at the local destination level, in some areas such as North Jutland with further support from the regional tourism development body (VisitNordjylland 2009). This strategy tried to exploit the temporal flexibility of the prevailing institutions by encouraging private producers of experiences and services to make their offerings available during a greater part of the year in a coordinated manner and thereby countering a classical dilemma of seasonality (see e. g. GetZ/NiLSSON 2004) through the creation of network-based trust between small private tourist firms within the destination. A second important element in destination-level all-year tourism strategies was to create further momentum by drawing on knowledge from outside the individual destination and by changing the status of actors such as restaurateurs from providers of standardised services to central attractions within the destination, thereby adding new value to the destination by profiling it through new types of experiences. Compared to extending the number of holiday homes, this initiative could readily be interpreted as an attempt to make use of the path plasticity inherent in the institutions governing Danish coastal tourism, and perhaps even the timing of the all-year initiative was also slightly better: its target groups were relatively well-off visitors potentially less affected by the financial crisis, and it was able to draw on the general interest, nationally and internationally, in "new Nordic cooking" that had burst onto unsuspecting diners earlier in the decade (see LARSEN 2011; MeYer 2012). But of course it still required both a positive response within the selected destinations and, in turn, from the potential out-of-season visitors targeted. In the following we will therefore focus on two typical Danish coastal destinations in order to get a better understanding of the challenges involved in extending the season for coastal leisure tourism in Denmark.

\section{Local responses}

Two destinations in North Jutland were designated as part of VisitDenmark's national initiative: destination Top of Denmark as a fully-fledged 
development destination, and Mariagerfjord as a second-tier learning destination operating on a limited budget and mainly benefitting from national support through access to knowledge and experience from other destinations within the project (Halkier et al. 2009; Henriksen/HaLKIER 2009; THERKELSEN 2010). The contrasting experience of the two destinations should be able to throw further light on the scope for exploring and exploiting path plasticity in tourism destination development.

The Top of Denmark destination originated as a joint venture between public and private tourism actors in the northernmost part of North Jutland. This area is dominated by a relatively uniform coastal tourism offer with long sandy beaches, holiday homes as the primary form of accommodation, and a string of more or less picturesque coastal towns (Henriksen/Halkier 2009). While the experience offers and visitors in the Top of Denmark destination thus epitomises the coastal tourism business model in North Jutland, the organisation of public tourism governance has clearly evolved from the fragmented localised model that used to characterise Danish tourism promotion at the local level. Traditionally each little town having its own independent Tourism Information Office, often supported through membership-based local tourist associations which tended to see neighbouring towns as their main competitors (ANDERSEN et al. 2000; HALKIER 2011). But in the Top of Denmark area a gradual process has taken place since the early 1990s that has brought formerly independent tourist offices together in a network organisation, designed so that local offices are involved in and perform functions for the network as a whole. This innovative organisational model has not only given the inter-local destination efficiency in terms of mobilising local financial and knowledge resources that can be employed in joined marketing and development projects, and the Top of Denmark activities gradually moved from joint marketing and services towards projects aiming to develop services and experiences through projects part-financed by external (European and/or national) sources (HENRIKSEN/ HALKIER 2009). This pattern was repeated in relation to VisitDenmark's all-year tourism initiative where national funding was supplemented by European funding channelled through the North Jutland Regional Growth Forum, something which increased the potential impact of the national initiative because it made it possible to instigate a range of development projects across the destination under the umbrella of what was termed Nature+. Activities included the setting up of eight thematic networks, bringing together tourism and other actors together around improving the communication of existing natural and cultural attractions with off-season relevance, and generating additional events in the quiet months (Toppen af Danmark 2009). These activities were designed on the basis not only of knowledge about products and demand patterns within the local tourism industry, but also drew on other forms of knowledge: in the strategy development phase knowledge of visitor trends from external sources played an important role (HALKIER et al. 2009), and the ensuing development projects were characterised by reaching stakeholders outside the tourism industry itself (e.g. anglers, arts and crafts entrepreneurs, a local manufacturer of stage lights to the international music business) (Toppen af Danmark 2009). In short, in the case of the Top of Denmark destination the attempt to further all-year tourism would seem to rely on the use and development of path plasticity: the basic institutions are still in place, but attempts are being made to reposition the use of existing facilities. This is primarily done by extending their use to a greater part of the year and by at the same time drawing on actors from outside the traditional accommodation-oriented core of the coastal tourism scene in order to add new cultural and nature-oriented experience offers to the existing portfolio. At the point of writing, no evaluation of the project has been undertaken, and therefore the response in terms of activities and visitation outside the main summer season is still unknown.

The experience of the Mariagerfjord destination is in many respects rather different. The destination is more heterogeneous in that traditional coastal tourism dominates the east coast, the picturesque small town of Mariager is predominantly visited by one-day tourists, extensive woodlands exist in the north, and the towns of Hadsund and Hobro primarily provide commercial services (THERKELSEN 2010). As a coastal tourist destination Mariagerfjord in other words constitutes a smaller version of Top of Denmark, with a strong beach product and added natural, cultural and commercial activities in the immediate hinterland. In terms of governance destination Mariagerfjord had been brought together in a rather loose manner in a new Tourism Council in 2007 as part of the preparation for the original bid to become part of the all-year tourism project, covering an area that merged into a 
single political unit in 2007 as part of a major reform of subnational government (HALKIER 2008; THERKELSEN 2010). When the destination was designated a learning destination by VisitDenmark with access to information rather than funding, VisitNordjylland provided financial support to address what had been identified as a major weakness of Mariagerfjord, namely a fragmented governance structure. Accordingly, the main activity associated with all-year tourism in Mariagerfjord was organisation building, with an extensive process facilitated by external private consultants with a long track-record in tourism-related matters that aimed to bring about a more integrated form of governance within the destination. Conversely, less time was spent on developing new experiences and services that might appeal to potential visitors outside the main summer season (THERKELSEN 2010). However, despite considerable efforts had been spent by local actors and external consultants, little progress had been made in terms of creating a destination-wide tourism development organisation accepted by key public and private stakeholders, and well-publicised inter-local wrangling continued. The outcome of the process has been that while all-year tourism remains part of the official strategy of the Mariagerfjord destination (VisitMariagerfjord 2010), in practice little progress would seem to have been made in terms of coordinated development efforts in this respect. In short, in the Mariagerfjord case policy efforts were initially concentrated on addressing the fragmented governance structure, drawing on external knowledge about both the general importance of and specific practices entailed in bringing stakeholders together around a destination-wide tourism development body. However, while this was an obvious weakness in the institutional set-up, it also meant that few possibilities were created for local public and private stakeholders to engage in joint and coordinated development of new services and experience that could prolong the coastal tourism season in the destination.

\section{Conclusion}

The analysis of the institutions governing the evolution of coastal leisure tourism in Denmark has demonstrated that strong elements of path dependency exist. The fit between visitor profiles and experience offers - families travelling with children and focusing on nature-based activities and relaxation - is obvious. More- over, the provision of experiences and services relies on a large number of small actors, many of whom (including individual owners of holiday homes) do not have tourism as their main source of income, and they are therefore inclined to operate on the basis of motives that are neither commercial nor driven by concerns for the development of tourism. In practice this has meant that activities promoting the development of e.g. a local coastal destination require extensive coordination activities, and in the absence of economically dominant private actors such as e.g. major hotels or tour operators, this function has been performed by public bodies. The dominant strategy pursued by actors in the Danish tourism policy network has been to use their coordinating clout to bolster existing activities, primarily through pre-travel promotion of Denmark and its destinations to potential visitors and on-site information services for visitors at individual tourist destinations. But at the same time another factor has helped to keep developments of coastal tourism on the same path, namely the regulation through planning measures of access to and construction of buildings and infrastructure in coastal areas, because this privileged existing structures - e.g. areas designated for holiday homes in the 1960s - and made it more difficult for potential competitors to enter e. g. the market for accommodation services aimed at coastal leisure tourists. From this perspective Fig. 2 could be interpreted as a destination development iron triangle, bound to deliver more of the same in a process characterised by a high degree of path dependency.

However, at the same time the analysis has also identified a general scope for incremental change, either through the use of existing institutions in innovative ways, or by making hitherto relatively marginal actors central to a renewed experience offer aimed to attract new types of tourists. The response of Danish policy-makers to the long-term stagnation in coastal leisure tourism is an interesting case in point: while the designation of new holiday home areas in the coastal hinterland was a conservative measure designed to make the more beds available in the high season, the attempt to further all-year tourism could readily be interpreted as an attempt to exploit the path plasticity of individual institutions and, indeed, by modifying the actor configuration. On the one hand the attempt to use holiday homes outside the main summer season makes use of the possibility that also-for-private-use accommodation can be made available 
also when days become shorter and temperatures lower. On the other hand developing the experience offer by highlighting cultural attractions such as local food brought traditionally rather marginal actors in the catering business - quality-oriented restaurateurs - and their associated forms of knowledge to the fore in an attempt to persuade visitors that coastal locations in North Jutland could be worth-while places to visit in November.

While assessing the result of the efforts has been complicated by the advent of the financial crisis, the difference between the two coastal destinations used as case studies would still seem to suggest the importance of effective policy agency and public-private partnership in achieving even incremental change in tourist destinations dominated by a large number of small actors. In the Top of Denmark case a decentralised network with an extensive degree of trust had previously been established in the attempt to boost developments along the existing path, but in times of crisis this governance set-up proved capable of changing direction in order to ensure continued development of the destination by embarking on experience innovation in search of all-year tourism. In contrast to this destination Mariagerfjord did not manage to make progress with regard to all-year tourism initiatives. Efforts concentrated on addressing the fragmented governance structure at the expense of concrete innovation activities, and thus despite the extensive introduction of external knowledge, local interests and perspectives continued to prevail. From this perspective, Fig. 2 no longer depicts an iron triangle but a rather more flexible structure which allows for a considerable degree of incremental change, provided that the actors involved are willing to engage in innovative development activities.

All in all the analysis would seem to support the usefulness of adopting an institutionalist path plasticity perspective for furthering the understanding of development and change in tourist destinations. The institutionalist perspective reminds us of the importance of the ties that bind in the form of e. g. market competition and ownership patterns which cannot be wished away or easily changed - and which therefore risk being taken for granted or ignored in analyses focusing more narrowly on public policies and their rationales. But, crucially, combining this continuity-oriented approach with a path plasticity perspective allows us to recognize that tourist destinations, like other socio-spatial phenomena, are not permanent structures. They are subject to change and reinvention, often of a small-scale incremental nature that it is difficult to detect by means of research designs that tend to background the temporal dimension and therefore operate in a binary now-or-never mode which juxtaposes current misery with future prosperity - and hence runs the risk of contributing to the perpetuation of the former.

\section{References}

Andersen, J./KvistgaArd, P. / Therkelsen，A. (2000): Turistforeningens rolle i fremtidens turisme i Nordjyllands Amt. Aalborg.

Bieger, T. / Wittmer, A. (2006): Air transport and tourism. Perspectives and challenges for destinations, airlines and governments. In: Journal of Air Transport Management, (12), 40-46.

BraczyK, H.-J. / CoOKe, P. / Heidenreich, M. (Eds.) (1998): Regional innovation systems. The role of governances in a globalized world. London.

Bramwell, B. / Cox, V. (2009): Stage and path dependence approaches to the evolution of a national park tourism partnership. In: Journal of Sustainable Tourism, (17)2, 191-206.

ButLER, R.W. (1980/2006): The concept of a tourist area cycle of evolution: Implications for management of resources (originally in Canadian Geographer 24, 1, 5-12). In: Butler, R.W. (Ed.): The tourism area life cycle. Vol. 1: Applications and modifications. Clevedon.

Butzin, A. / Helmsträdter, E. / Larsson, A. / Macneil, S. / VAle, M./Widmaier, B. (2007): Guidelines to the WP6 firm level case studies. Birmingham.

Butzin, A. / Widmaier, B. (2012): The study of time-space dynamics of knowledge with innovation biographies. Marburg. (Marburg Geography, 7/2012).

Cassel, S.H./PAshKevich, A. (2008): Heritage tourism and inherited institutional structure. The case of Falun Great Copper Mountain. In: Scandinavian Journal of Hospitality and Tourism, (11)1, 54-75.

Cooke, P. / Heidenreich, M. / BraczyK, H.-J. (Eds.) (2004): Regional innovation systems. The role of governance in a globalized world. Abingdon. (2nd ed.)

Crevoisier, O./ JeAnNerat, H. (2009): Territorial knowledge dynamics: From the proximity paradigm to multilocation milieus. In: European Planning Studies, (17)8, 1223-1241.

Dredge, D. (2006): Policy networks and the local organisation of tourism. In: Tourism Management, (27)2, 269-280.

Getz, D. / Nilsson, P. Å. (2004): Responses of family businesses to extreme seasonality in demand. The case of Bornholm, Denmark. In: Tourism Management, (25), 17-30.

Gill, A.M./Williams, P.W. (2011): Rethinking resort growth. Understanding evolving governance strategies in Whistler, British Columbia. In: Journal of Sustainable Tourism, (19)4-5, 629-648. 
HALKIER, H. (2006): Institutions, discourse and regional development. The Scottish Development Agency and the politics of regional policy. Brussels.

HALKIER, H. (2008): Regional development policies and structural reform in Denmark. From policy segmentation towards strategic synergy? In: Bukve, O. / Halkier, H. / Souza, P.D. (Eds.): Towards new Nordic regionalism. Politics, administration and regional development. Aalborg, 201-225.

HALKIER, H. (2010a): EU and tourism development: Bark or bite? In: Scandinavian Journal of Hospitality and Tourism, (10)2, 92-106.

HALKIER, H. (2010b): Tourism knowledge dynamics. In: Cooke, P. / Laurentis, C. D. / Collinge, C. / MacNeill, S. (Eds.): Platforms of Innovation. Dynamics of new industrial knowledge flows. London, 233-250.

HALKIER, H. (2011): Erhvervspolitik mellem det lokale og det globale? Dansk turismepolitik under forandringspres. In: Økonomi \& Politik, (84)4, 11-24.

Halkier, H. / Henriksen, P. F. / Dahl Olesen, L. / TherkelSEN, A. (2009): Knowledge dynamics in tourism in North Jutland. Case studies of knowledge events within coastal and cultural tourism: EURODITE WP6 FKD final report. Birmingham.

Hall, C. M. (2008): Tourism planning. Policies, processes and relationships. Harlow. (2nd ed.)

Hall, C. M. / Müller, D. K. / SAARInEN, J. (2009): Nordic tourism. Issues and cases. Bristol.

Hall, C. M. / Page, S. J. (2002): The geography of tourism and recreation. Environment, place and space. London. (2nd ed.)

Hall, C. M. / Williams, A. (2008): Tourism and innovation. Abingdon.

HANSEN, E. (2006): Helårskystturisme. Afgrænsning, erfaringer og muligheder. København.

HASsink, R. (2005): How to unlock regional economies from path dependency? From learning region to learning cluster. In: European Planning Studies, (13)4, 521-535.

HENRIKSEN, P.F. (2012): Small tourism firms' inter-organisational relations and knowledge processes: The role of social embeddedness in networks: The case of the municipality of Viborg, Denmark. Aalborg. (Culture and Global Studies, Aalborg University).

Henriksen, P.F. / Halkier, H. (2009): From local promotion towards regional tourism policies. Knowledge processes and actor networks in North Jutland, Denmark. In: European Planning Studies, (17)10, 1445-1462.

HJalager, A.-M. (2002): Repairing innovation defectiveness in tourism. In: Tourism Management, (23), 465-474.

HJALAGER, A.-M. (2009): Udviklingsdynamikker i sommerhussektoren. Århus.

HJalager, A.-M. (2010): A review of innovation research in tourism. In: Tourism Management, (30)1, 1-12.

HJalager, A.-M. / Huijbens, E. H. / BJÖRK, P. / Nordin, S. / Flagestad, A. / KNútSSON, Ö. (2008): Innovation systems in Nordic tourism. Oslo.

HJalager, A.-M. / Jensen, S. (2001): Nordjylland - en turismeregion i Danmark. In: Nordregio Working Paper, 11, $47-70$.
IoAnnides, D. / Debage, K. G. (Eds.) (1998): The economic geography of the tourist industry. London.

Kernel, P. (2004): Creating and implementing a model for sustainable development in tourism enterprises. In: Journal of Cleaner Production, (13),151-164.

KvistgaARD, P. (2006): Problemer og magt i regional turismepolicy. Aalborg.

LAGIEWSKI, R. M. (2006): The application of the TALC mode: A literature survey. In: Butler. W. (Ed.): The tourism area life cycle. Vol. 1: Applications and modifications. Clevedon, 27-50.

LARSEN, H. P. (2011): Performing tasty heritage. Danish cuisine and playful nostalgia at restaurant noma. In: Ethnologia Europaea, (40)2, 90-102.

LARSEN, J. R. K. (2012): Family holiday homescapes. Place, individual and social perspectives on the intra-family experience dynamics at the holiday home destination. Aalborg. (Department of Culture and Global Studies, Aalborg University).

Larsen, J. R. K. / Laursen, L. L. H. / Therkelsen, A. (2012): Feriehusområder i Nordjylland - et landskab med oplevelsespotentiale. In: Christensen, J. L. (Ed.): Nordjyske udviklingsperspektiver - afvikling eller udvikling? Aalborg, 231-257.

LARSEN, J. R. K. / THERKELSEN, A. (2011): Et efterspørgselsperspektiv på samspillet mellem feriehus, feriehusområde og attraktioner. In: Økonomi \& Politik, (84)4, 40-55.

LuNDVALL, B.-K. (Ed.) (1992): National systems of innovation. Towards a theory of innovation and interactive learning. London.

Mahoney, J. / Thelen, K. (2010): A theory of gradual institutional change. In: Mahoney, J./Thelen, K. (Eds.): Explaining institutional change. Cambridge, 1-37.

MALERBA, F. (Ed.) (2004a): Sectoral systems of innovation. Concepts, issues and analyses of six major sectors in Europe. Cambridge.

MALERBA, F. (2004b): Sectoral systems of innovation. Basic concepts. In: Malerba, F. (Ed.): Sectoral systems of innovation. Concepts, issues and analyses of six major sectors in Europe. Cambridge, 9-41.

Martin, R. / Sunley, P. (2006): Path dependence and regional economic evolution. In: Journal of Economic Geography, (6), 395-437.

Meyer, C. (2012): The new Nordic cuisine Movement. Internet: www.clausmeyer.dk.

Niras Konsulenterne (2006a): Analyse af potentialet for sæsonforlængelse og helårskystturisme. København.

Niras Konsulenterne (2006b): VisitDenmark vækstprojekt Helårskystturisme. Udpegning af 23 destinationer. Analyse af potentialet for sæsonforlængelse og helårskystturisme. København.

NORTH, D.C. (1990): Institutions, institutional change and economic performance. Cambridge.

Novelli, M. / Schmitz, B./ Spencer, T. (2006): Networks, clusters and innovation in tourism: A UK experience. In: Tourism Management, (27), 1141-1152.

NyBERG, L. (1995): Scandinavia. Tourism in Europe's northern periphery. In: Montanari, A./Williams, A. M. (Eds.): 
European tourism. Regions, spaces and restructuring. Chichester, 87-107.

OECD (Ed.) (2006): Innovation and growth in tourism. Paris.

OLSEN, L.S. (2012): Territorial knowledge dynamics: Making a difference to territorial innovation models and public policy? In: European Planning Studies, (20)11, 1785-1801. Økonomi- og Erhvervsministeriet (2006): Redegørelse af 25. januar 2006 om Dansk turisme. København.

SHAW, G. / Williams, A. M. (1998): Entrepreneurship, small business culture and tourism development. In: Ionannides, D. / Debbage, K. G. (Eds.): The economic geography of the tourist industry. London, 235-255.

Skov- og Naturstyrelsen (2007): Landsplandirektiv for 14 sommerhusområder i kystnærhedszonen i Region Nordjylland. København.

Statistics Denmark (2012): Tourism data warehouse. Copenhagen. Internet: www.dst.dk, 14.8.2012.

Strambach, S. (2010): Path dependence and path plasticity: The co-evolution of institutions and innovation - the German customised business software industry. In: Boschma, R. / Martin, R. (Eds.): The Handbook of Evolutionary Economic Geography. Cheltenham, 406-431.

Strambach, S./Halkier, H. (2013): Reconceptualising change. Path dependency, past plasticity and knowledge combination. In: Zeitschrift für Wirtschaftsgeographie this vol.

Strambach, S. / Klement, B. (2012): Cumulative and combinatorial micro-dynamics of knowledge. The role of space and place in knowledge integration In: European Planning Studies, (20)11, 1843-1866.

THELEN, K. (2009): Institutional change in advanced political economies. In: British Journal of Industrial Relations, (47)3, 471-498.

Therkelsen, A. (2010): Being or becoming in the know. A case study of knowledge processes at a Danish tourism destination. In: TRUprogress 7.
Therkelsen, A. / Larsen, J. R. K. / Laursen, L. L. H. / HaLKIER, H. (2012): Fremtidens feriehus \& feriehusområde. Et landskab af hybride oplevelser. Aalborg. (Aalborg Universitet, Institut for Kultur og Globale Studier).

Thorelli, H. B. (1986): Networks. Between markets and hierarchies. In: Strategic Management Journal, (7)1, 37-51.

Toppen af Danmark (2009): Naturen+ i Lysets land. Handlingsplan for vikling af helårsturisme i Toppen af Danmark 2009-2011. Frederikshavn.

VisitDenmark (2005): Feriehusundersøgelse 2005. København.

VisitDenmark (2007a): Kystferiestrategi i retning mod helårsturisme. København.

VisitDenmark (2007b): The Scandinavian destinations' tourism performance 2000-2006. København.

VisitDenmark (2007c): Syv destinationer skal skabe fornyet vækst i dansk turisme. København.

VisitDenmark (2010a): Denmark's tourism performance in Europe 2000-2009. København.

VisitDenmark (2010b): Turismen i region Nordjylland i tal. København.

VisitDenmark (2012): Turismens økonomiske betydning i Nordjylland. København.

VisitMariagerfjord (2010): Turismestrategi 2010-2012. Hobro.

VisitMariagerfjord (2009): Årsberetning 2008. Åbybro.

VisitNordjylland (2009): Årsberetning 2008. Åbybro.

Weaver, D./Lawton, L. (2002): Tourism management. Milton. (2nd ed.).

WeIERMAIR, K. (2006): Product improvement or innovation. What is the key to success in tourism? In: OECD (Ed.): Innovation and growth in tourism. Paris, 53-69.

Williams, A. M. / Balaz, V. (2002): The Czech and Slovak Republics. Conceptual issues in the economic analysis of tourism in transition. In: Tourism Management, (23)1, $37-45$. 